Nancy L. Staub, Gonzaga University, Lawrence S. Blumer, Morehouse College, Christopher W. Beck, Emory University, Véronique A. Delesalle, Gettysburg College, Gerald D. Griffin, Tuskegee University and Hope College, Robert B. Merritt, Smith College, Bettye Sue Hennington, Tougaloo College, Wendy H. Grillo, Gail P. Hollowell, Sandra L. White, North Carolina Central University, Catherine M. Mader, Hope College

\title{
- Course-based Science Research Promotes Learning in Diverse Students at Diverse Institutions
}

\begin{abstract}
Course-based research experiences (CREs) are powerful strategies for promoting learning and persistence for all students, both science majors and nonscience majors. Here we address the crucial components of CREs (context, discovery, ownership, iteration, communication, presentation) found across a broad range of such courses at a variety of academic institutions. We also address how the design of a CRE should vary according to the background of student participants; no single CRE format is perfect. We provide a framework for implementing CREs across multiple institutional types and several disciplines throughout the typical four years of undergraduate work, designed to a variety of student backgrounds. Our experiences implementing CREs also provide guidance on overcoming barriers to their implementation.
\end{abstract}

Keywords: course-based research experiences, inquiry, laboratories, undergraduate research

Historically, undergraduate research was only for the fortunate few who earned a position in a faculty research lab, often in preparation for graduate school. However, the benefits of undergraduate research experiences extend beyond training for graduate or professional school. Students show improved outcomes through research experiences, for example in improved skills in critical thinking and data analysis and increased confidence in doing science (Corwin et al. 2015; Lopatto 2004; Seymour 2004; Thiry 2012). These experiences then translate into increased student persistence in science, including for underrepresented minorities (Eagan et al. 2013; Graham et al. 2013; Wilson et al. 2012). Course-based research experiences (CREs) are powerful strategies to spread these gains in learning and persistence to all students, both science majors and nonscience majors (AAAS 2011). Because learning gains and attitudinal changes can be dramatic with CREs, reforming undergraduate, course-based, laboratory experiences to include experiential learning through hands-on research will provide the benefits of undergraduate research to more students and to a more diverse population (Bangera and Brownell 2014).

This article addresses the crucial components of CREs found across a broad range of undergraduate courses in several disciplines at different types of academic institutions. It also discusses how to implement CREs appropriate to the level or background of the student participants. Our institutions (see Table 1) include both public and private universities and liberal arts colleges, which vary in admissions selectivity and student preparation. Both the universities and liberal arts colleges include minority-serving institutions. We acknowledge that no single CRE format is perfect. What an authentic research experience is for a senior physics major will be very different from that for a senior biology major, and these senior experiences will necessarily differ from those designed for freshmen.

In addition to discipline-specific variations, the best coursebased research experience for students depends on who the students are and where they are enrolled. Course-based research for freshmen at a large public university may well be different from that for freshmen at a small liberal arts college. The learning objectives for the specific course must guide development of the course-based research. We will provide a framework for understanding the implementation of CREs across multiple institutional types, disciplines, academic levels, and student backgrounds; in short, context matters. Our experiences implementing CREs provide guidance for overcoming barriers to implementation regardless of the specific institutional context.

In the real world of work, no one would propose to train practitioners by having them read books or listen to lectures to the exclusion of practice in their field. Artists learn to paint by viewing the work of the masters and then actually drawing and painting. Plumbers learn their trade by repairing leaks. Pastry chefs learn to bake by tasting a fine cake and then practicing the process of actually making a cake. Similarly, if our goal is to train future scientists and scientifically informed citizens, we must provide a meaningful context and then let students actually do science. We have found that it is not necessary to have a methods course in which students practice methods without a research purpose. All the course-based research experiences we have implemented have immediately engaged students in the process of conducting science.

\section{What Is a CRE?}

Course-based research experiences (CREs) are often thought to be at the end of a continuum of teaching approaches in laboratory courses, ranging from traditional "cookbook" labs 
Table 1. Characteristics of Diverse Institutions Contributing to Course-based Research Experiences (CRE) Study

\begin{tabular}{|l|l|l|l|l|l|}
\hline Institution & Public/private type* & HBCU? & $\begin{array}{l}\text { Undergraduate } \\
\text { enrollment }\end{array}$ & $\begin{array}{l}\text { Average ACT or SAT score total } \\
\text { school GPA }\end{array}$ \\
\hline Emory University & Private, University & No & 7,829 & SAT total 2010-2250 & $3.69-3.98$ \\
\hline Gettysburg College & Private, Liberal Arts & No & 2,600 & $\begin{array}{l}\text { ACT composite 26-30 } \\
\text { SAT composite 1210-1360 }\end{array}$ \\
\hline Gonzaga University & Private, Liberal Arts & No & 5,000 & ACT composite 26.8 SAT composite 1196 & 3.7 \\
\hline Hope College & Private, Liberal Arts & No & 3,342 & ACT total 23-29 SAT total 1070-1290 & 3.77 \\
\hline Morehouse College & $\begin{array}{l}\text { Private, Liberal Arts, } \\
\text { Men's College }\end{array}$ & Yes & 2,189 & ACT total 18-23 & 2.50- 2.99 \\
\hline North Carolina Central University & Public, University & Yes & 6,220 & SAT 889 (Math and Verbal) & SAT total 1830-2150 \\
\hline Smith College & $\begin{array}{l}\text { Private, Liberal Arts, } \\
\text { Women's College }\end{array}$ & No & 2,606 & ACT composite 18 SAT composite 853 & 2.0 \\
\hline Tougaloo University & Private, Liberal Arts & Yes & 878 & ACT composite 18/22 & 3.9 \\
\hline Tuskegee University & $\begin{array}{l}\text { Private/Land-Grant, } \\
\text { University }\end{array}$ & Yes & 3,156 & 3.24 \\
\hline
\end{tabular}

*Type: "University" indicates that graduate programs (master's and/or PhDs) are offered in a variety of programs. "Liberal Arts" institutions are those that only offer undergraduate degrees (in the sciences) or have very limited graduate programs.

HBCU: Historically Black Colleges and Universities

to guided-inquiry to open-ended inquiry to CREs (Buck et al. 2008; Auchincloss et al. 2014; D'Avanzo 1996; Weaver et al. 2008). CREs are alternatively called course-based undergraduate research experiences (CUREs) (Auchincloss et al. 2014), teacher-collaborative inquiry (D'Avanzo 1996), authentic inquiry (Buck et al. 2008), and research-based labs (Weaver et al. 2008). Spell et al. (2014) note that definitions of CREs focus on either scientific process (e.g., experimental design) or scientific products (e.g., new discoveries), although both can be considered essential components of a CRE (Auchincloss et al. 2014).

The degree to which the scientific process or scientific products are emphasized in a CRE might vary depending on course level or the specific learning objectives of the course. At the introductory level, faculty might emphasize scientific process over products (Spell et al. 2014). However, when faculty implement CREs that are part of a larger national project (e.g., SEA-PHAGES, Jordan et al. 2014; Genomics Education Partnership, Shaffer et al. 2010), scientific products become equally or more important.

While considering previous definitions of CREs (Auchincloss et al. 2014; Spell et al. 2014; Weaver et al. 2008), we have identified components that are common to our implementation of CREs across diverse institutions. Our focus is to describe these elements and highlight the diversity of CRE activities that embody them, noting that not every element may be necessary for a successful CRE experience. Exactly how CREs lead to improved student outcomes in different contexts is as yet unknown (Corwin et al. 2015). Figure 1 shows the common elements in our CREs.

\section{Figure 1. Common Elements in CREs}

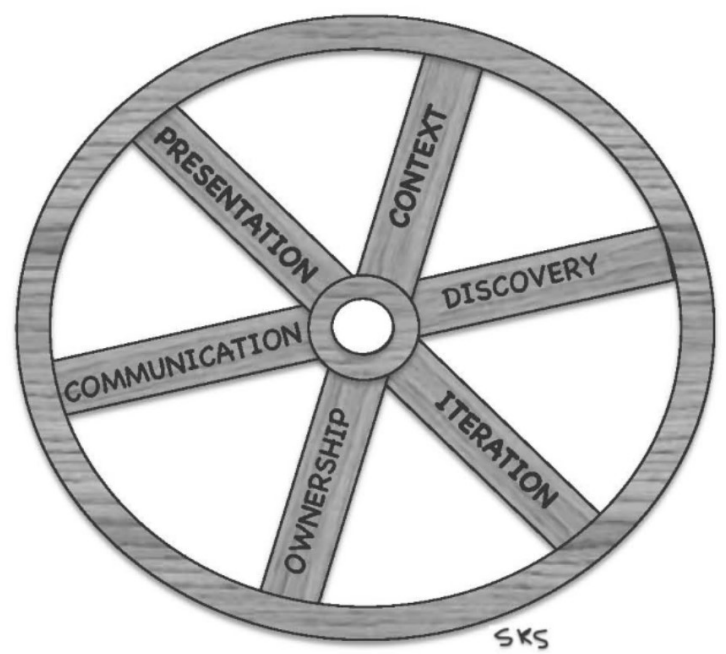

The wagon wheel illustrates the common elements in CREs, which occur progressively in the research process, starting with Context and progressing clockwise. 
Context. How a CRE is presented to students is critical for its successful implementation. Providing the context should include an explanation of the research question and its importance. Creating relevance for students is an essential first step in any research project (e.g., Siritunga et al. 2011). That relevance for students may come from understanding that they are contributing to a national database (e.g., phage or Drosophila genomes), addressing issues relevant to the local communities (e.g., mercury poisoning), or contributing to a professor's own research program. The manner in which the context of research is conveyed depends on the student's academic level (e.g., general discussion of science and the importance of asking questions versus reading primary literature). End-of-course surveys generally reveal that context is important to students. The following remarks by our students illustrate this:

- "It has broadened my understanding of science; there is so much potential in phage research for medicine that is totally unexplored."

- "This class really encourages students to think about genetics not as a field of fixed knowledge but as an expanding body of work in which many questions have yet to be answered."

- "Primary literature was a huge part of what made this course such a valuable learning experience. I feel like I've grown a lot as a scientist by reading and analyzing these papers."

Discovery. Addressing a question for which the specific answer is not known and contributing new knowledge to the field are the essence of discovery. Examples of CRE projects that involve discovery include describing a new bacteriophage, determining environmental factors for optimal yeast growth, evaluating the critical nutrients for the development of bean beetles, fabricating nanoparticles to limit bacterial growth, and assessing mercury contamination and biogeochemical cycling in a local watershed.

Diagnostic research (such as personal genotyping for blood type, karyotype analysis, mitochondrial DNA sequencing, DNA fingerprinting, and PTC taster genotyping) can be included in discovery as long as students do not know the outcome prior to conducting their studies. Discovery is a key element as it leads to the students' sense of commitment and excitement about the research, as demonstrated in the following comments:

"My first [discovery] moment was the first time that plaques appeared on our plates. Prior to that we were hoping and wishing we had collected phage and were just doing procedures and I wasn't that interested as I was simply following protocols, but once the plaques appeared my mindset changed and I actually began to realize the significance of what we were doing. I was now intrigued to be learning more about the phages."

- "My biggest [discovery] moment occurred when we received our TEM images back. Actually being able to visualize a microscopic virus that you had been working so hard to isolate and to locate was a very substantial feeling and made everything we had done and worked on worth it."

Ownership. The element of ownership is a natural consequence of the discovery process, but it also is important in its own right. Students' sense of ownership of the research experience is manifested in a variety of ways such as designing an experiment, trouble-shooting a protocol until it actually works, naming a discovered virus or describing a new species, or producing results that contribute to a publishable manuscript. Ownership means that students feel they have a stake in the research being conducted. For example, students commented:

- "It has showed me that I, even being this young, can think like a true scientist and do experiments that actually contribute to society."

- "When we had to go into lab to redo the concentration of DNA I had realized how much dedication this field calls for like any other field. This has influenced me to work hard in everything I do and be prepared to give my time in all of my career goals."

Iteration. Discovery and ownership lead to the realization that collecting reliable and reproducible results often requires repeating procedures or entire experiments, as advancing in a research project only occurs once necessary procedures have been mastered successfully. In contrast with traditional laboratories with prescribed methods, what iteration means for students is that they are expected to repeat procedures until they work-for example, until they get phage plaques, their gel has bands, or their fast plants don't die due to neglect. Iteration fosters mastery of techniques and understanding of the process, and thus enhances the students' sense of ownership. As one said:

"When we were doing plaque streaking I had to show up by myself to do it, and for the life of me, I could not figure out how to do it, and after wasting many sticks and many viable plaques, I finally understood it, and I was really excited about it because what had seemed so 
difficult on paper suddenly made sense in my head."

Communication. Becoming fluent in the language of science and the language of the specific research project requires that students discuss background information, methods, results, troubleshooting ideas, and data interpretation and implications with other members of the research community-whether that occurs within a course or across two linked courses (for example, linking a biology and a chemistry course investigating water quality using their different disciplinary perspectives). Research shows that talking about course material facilitates student learning (Tanner 2009), and encouraging students to talk applies to the research lab as well.

Campbell and Lom (2006) suggest an email question-and-answer tool to facilitate learning, communication, and self-reflection in undergraduate research labs. Their five questions-How have you spent your time? What do you know? What don't you know? How can you find out what you don't know? What are your frustrations?-could be incorporated into a CRE to encourage communication among students as well as their independence over time. Conversation facilitates students' understanding of not only the scientific process but also of the significance and intellectual underpinnings of the research itself.

Learning to communicate science effectively through writing is another key ingredient of CREs. Lab reports, research summaries, essays for a more general audience, and poster presentations are different ways of practicing this skill. One student noted:

- "It gave me a much greater appreciation for all the work that goes into a [scientific] paper."

Presentation. In addition to communication within a laboratory/course environment, presenting research findings to an outside audience is another critical element of a CRE. Such student presentations reinforce the relevance and significance of their research; students realize that others are, in fact, interested in their discovery. Presentations may range from poster sessions or oral presentations at local or regional symposia and reports to external stakeholders to presentations at a national or international science conference. For example, students at Hope College in a variety of CRE courses study aspects of the local watershed. Many of these students present their findings to the technical committee of a metropolitan planning organization, which also broadcasts the meeting on the local public-access television channel. Including presentation opportunities in CREs reinforces the context of the research and also helps to develop specific scientific communication skills, as the following quote from one student demonstrates:

- "The group presentations were also very helpful and although the final paper is putting a lot of stress on me at this time, I believe it will be a good way to show what we've learned in this course and how we can apply it to future studies."

Given that all the components of CREs may not be present within one module or even in a semester-length CRE, it is valuable for institutions to consider how these essential elements can be met across the sequence of courses that students take during the typical four-year curriculum. Whether learning gains differ between modular and semester-long research experiences is unknown. The learning gains from semester-long CREs are comparable to the more traditional summer-immersive research experience, however (Staub et al. 2016). A comprehensive study of a variety of short-term, semester-long, and summer experiences would be a valuable contribution to understanding the educational impact of different CREs.

\section{Implementing Course-based Research}

Across the authors' diverse institutions and course contexts, we found that CRE implementation works best when well-tailored to the level of the students and to the available resources. For example, freshmen at one institution may conduct course-based research that includes scaffolding activities to introduce them to a system and its relevant techniques (see for example, North Carolina Central University's entries in Table 2), while freshmen at another institution may be immersed in a full semester of course-based research (see Smith College, Table 2). At another institution, majors may be engaged in a full-semester CRE along with nonscience majors (Gonzaga University, Table 2). CRE implementation occurs in many ways; in the following section we describe specific implementation strategies from our diverse institutions and compare the advantages and disadvantages of modular and semester-length CREs.

Implementing CREs requires a commitment by faculty to provide meaningful context for the research projects, a willingness to ask questions of students rather than answer students' questions, and the patience to provide research mentoring in the laboratory. In addition to the personal commitment by faculty, laboratory coordinators are essential for some CREs.

Curricular Considerations. While considering whether or not to offer a CRE, it is important to consider the course in relation to the department's curricular requirements. For exam- 
Table 2. Examples of Course-based Research at Authors' Institutions

\begin{tabular}{|c|c|c|c|}
\hline Discipline & Implementation & Title/description & Institution \\
\hline \multicolumn{4}{|c|}{ Nonscience majors } \\
\hline Biology & Modular & Essential nutrients in the diet of bean beetles & Emory University \\
\hline Biology & Full semester & Phage Hunters & Gonzaga University \\
\hline Biology & Modular & Use of spices to reduce food-borne pathogens & Hope College \\
\hline $\begin{array}{l}\text { Biology/ } \\
\text { Environmental } \\
\text { Studies }\end{array}$ & Modular & Indigenous Science & Gonzaga University \\
\hline \multicolumn{4}{|c|}{ First-year science, mathematics, and engineering majors } \\
\hline Biology & Modular & Molecular investigation of dog coat characteristics & Hope College \\
\hline Biology & Modular & Effects of pharmaceuticals in wastewater on aquatic organisms & Hope College \\
\hline Biology & Modular & Cellular and Genetic Biology (specific project topic varies) & Tuskegee University \\
\hline Biology & Full semester & Molecular responses to DNA damage & Gettysburg College \\
\hline Biology & Full semester & Global amphibian declines and bacterial symbionts & Gettysburg College \\
\hline Biology & Full semester & Biochemical factors affecting yeast fermentation & NC Central University \\
\hline Biology & Full semester & Phage Hunters & Gonzaga University \\
\hline Biology & Full semester & Organisms and diversity, metabolic and genetic differences & NC Central University \\
\hline Biology & Full semester & Testing anti-microbial compounds using Listeria monocytogenes & Tuskegee University \\
\hline Biology & Full semester & Organismal Biology (specific project topic varies) & Tuskegee University \\
\hline Biology & Full year & Phage Hunters & Morehouse College \\
\hline Biology & Full year & Phage Hunters & Hope College \\
\hline Biology & Full year & Phage Hunters & Gettysburg College \\
\hline $\begin{array}{l}\text { Biology/ } \\
\text { Geology }\end{array}$ & Full year & Mercury cycling in the watershed & Smith College \\
\hline Chemistry & Modular & Biochemical or environmental stressors on cellular processes & Tougaloo College \\
\hline Engineering & Modular & Introduction to Engineering - Engineering Design Project & Hope College \\
\hline Statistics & Modular & Statistics and the Great Lakes & Hope College \\
\hline \multicolumn{4}{|c|}{ Sophomore science majors } \\
\hline Biology & Modular & In-silico phage hunters & Gonzaga University \\
\hline Biology & Modular & Field ecology & Gonzaga University \\
\hline Biology & Modular & Physiology & Gonzaga University \\
\hline Biology & Modular & $\begin{array}{l}\text { Biochemical and/or environmental stressors on cellular processes } \\
\text { (Saccharomyces cerevisae) }\end{array}$ & Tougaloo College \\
\hline Biology & Full semester & Biochemical or environmental stressors on cellular processes & NC Central University \\
\hline Biology & Full semester & Animal Physiology & Tuskegee University \\
\hline Chemistry & Half-semester & Independent organic synthesis & Hope College \\
\hline \multicolumn{4}{|c|}{ Junior/senior science majors } \\
\hline Biology & Modular & Student-directed independent biodiversity research & Gonzaga U. Summer:Chimfunshi, Zambia \\
\hline
\end{tabular}


Table 2: continued

\begin{tabular}{|c|c|c|c|}
\hline Discipline & Implementation & Title/description & Institution \\
\hline \multicolumn{4}{|c|}{ Junior/senior science majors } \\
\hline Biology & Modular & Student-directed independent physiology research & Gonzaga University \\
\hline Biology & Modular & Student-directed independent ecology research & Emory University \\
\hline Biology & Modular & Conservation Biology laboratory & Gonzaga University \\
\hline Biology & Half-semester & Comparative Endocrinology & Gonzaga University \\
\hline Biology & Half-semester & Student-directed independent microbiology research & Gonzaga University \\
\hline Biology & Full semester & Advanced Phage Hunters & Gonzaga University \\
\hline Biology & Full semester & Parasitology & Tuskegee University \\
\hline Biology & Full semester & Laboratory Animal Science & Tuskegee University \\
\hline Biology & Full semester & Introduction to Research; Biomedical & Tougaloo College \\
\hline Biology & Full semester & Immunology & Tougaloo College \\
\hline Biology & Full semester & Bacterial molecular responses to oxidative stress & Gonzaga University \\
\hline Biology & Full semester & General Neurobiology & Tuskegee University \\
\hline Biology & Full year & Neuroscience capstone & Hope College \\
\hline $\begin{array}{l}\text { Biology/ } \\
\text { Environmental } \\
\text { Studies }\end{array}$ & Modular & Climate change effects on bean beetles & Morehouse College \\
\hline Chemistry & Full semester & Nanobiotechnology & Tuskegee University \\
\hline $\begin{array}{l}\text { Environmental } \\
\text { Science }\end{array}$ & Full semester & Environmental Science Capstone & Hope College \\
\hline Physics & Modular & Introduction to Physics II & Tougaloo College \\
\hline
\end{tabular}

ple, when first developing a CRE, it may be valuable to start small with one lab section and make the CRE an elective for students. In the long term, however, CREs as electives don't work well unless they also satisfy requirements for a major. Because science majors generally carry a high credit load, offering a course as an elective typically results in low numbers of participants. Sustainability is difficult with low student numbers and, consequently, designing your CRE as a replacement for-or as a curricular equivalent of - a traditional lab contributes to its longevity.

Choosing the Research Question. After the decision to offer a CRE, choosing an accessible research topic is key. The options are limitless, but several common approaches include a CRE based on a faculty member's research project, a CREmodel system, or an issue of concern to the local community. There are trade-offs with each approach. For example, model systems have the advantage that the background material and research questions are readily available and CRE implementation is well structured-for example, SEAPHAGES (Hatfull 2015), p53 mutations in yeast (Brownell et al. 2015), and bean beetles (Beck and Blumer 2014; http://www.beanbeetles.org/). These model systems are consequently convenient CREs to offer and thus are used at a variety of institutions. However, faculty expertise and passion at a given institution is necessary as well for successful implementation.

As noted above, providing context for the CRE project is key. If the CRE is based on a faculty member's research program, as many upper-division CREs are, providing context tends to be straightforward, since the faculty member is familiar with particular readings that can be shared with students. For other types of CREs, providing context varies from having students read primary literature, interact with business partners, and/or read secondary literature and handouts. For example, students in introductory-level CREs at North Carolina Central University are provided handouts with background material concerning their yeast-model system. Later in the curriculum at NC Central University, in the capstone CRE, students read primary literature to provide the context for designing their own experiments. 
This approach is similar to that in the upper-level ecology lab at Emory University, in which students develop their own context by reading primary literature. For this CRE, students are responsible for designing their project from the ground up, so they do their own background reading to establish the context and significance of their work. For a freshman-level SEA-PHAGES-based CRE that includes both science and non-science majors, context is provided by having the students read secondary literature "All the world's a phage, " Travis 2003) and chapters from "A Planet of Viruses" (Zimmer 2012).

Another common approach to providing context is basing the CRE on a local environmental issue or community need. At Smith College, a year-long interdisciplinary CRE on the biogeochemical cycling of mercury in the local watershed is offered to freshmen. In the introductory engineering course at Hope College, the meaningful context comes from the "community customer." For example, an elderly person might request a device to help pull up socks, or a quadriplegic might describe the need for a snack dispenser fitted to his wheelchair. The students then work on project design, interview the customer again at mid-semester for feedback, and then do a final presentation at the end of the semester on their design prototype. In a different community-based modular CRE at Hope College, students gather data on a threatened species (Pitcher's thistle) during a precollege field program. Context is provided by reading primary literature and books. During the semester, students then design and carry out projects on some aspect of Great Lakes environmental issues using historical data collected by the class or from available online databases. In summary, context can be provided from multiple sources depending on the level of the student and the course.

Commitment of CRE Instructors. Regardless of the type of CRE research project chosen, the faculty, staff, and teaching assistants involved need to be pedagogically committed to fostering a genuine research experience. Although often the faculty members participating in CREs have strong commitments to undergraduate teaching and mentoring, others in the department may need to become familiar with the specific demands of translating research into a CRE. Intentionally reviewing successful mentoring strategies with the CRE faculty, support staff, and TAs is the first step. Shellito et al. (2001) provide a solid framework of mentoring suggestions, ranging from practical advice such as "develop well-defined projects with student interest and ability in mind" and "recognize and respect student time commitments outside of the laboratory," to tips on developing effective relationships such as "know your students as individuals" and "respect students as colleagues." Although these tips were written with the im- mersive undergraduate summer experience in mind, developing a CRE built on these principles will serve students well. Students are quick to note the difference in attitude between CRE labs and others. For example, one student wrote: "I can say that I also loved this course probably because of how they treated the students as equals and 'colleagues' rather than as students and expected so much of us."

For courses with multiple instructors and teaching assistants, this pedagogical training and commitment is crucial for successful CRE implementation. National organizations such as the Council on Undergraduate Research offer CRE-based workshops, and professional societies may do the same at national conferences. Several National Science Foundationfunded Research Coordination Networks in Undergraduate Biology Education (RCN-UBE) also offer workshops or networking opportunities for faculty interested in CREs (e.g., CUREnet, curenet.cns.utexas.edu; REIL-Biology, rcn.ableweb. org; EREN, erenweb.org; GCAT SEEK, lycofs01.lycoming. edu/ gcat-seek/). Many of the authors' institutions routinely offer workshops for their own faculty, teaching assistants (graduate or undergraduate), and any other personnel involved in the CRE at the start of each semester in order to review content and pedagogical goals. Other institutions have weekly meetings to review week-to-week procedures, as well as offer reminders of pedagogical principles.

\section{Supporting Course-based Research}

Although the traditional SEA-PHAGES (Science Education Alliance-Phage Hunters Advancing Genomics and Evolutionary Science) model has two faculty members and a teaching assistant per lab section, if that level of resource commitment is not possible, other models work as well. For introductory-level CREs serving large numbers of students, North Carolina Central University uses one faculty member, one undergraduate $\mathrm{TA}$, one graduate $\mathrm{TA}$, and one postdoc to run each section. This strategy is critical due to the demographics of the student population. Many arrive at the university with no research experience and few lab skills. In a different model, Gonzaga University uses one faculty member and one teaching assistant to run labs for a large freshman CRE, with additional teaching assistants staffing open labs. In contrast, for CREs serving smaller numbers of students, labs often are run by faculty without the assistance of teaching assistants.

In addition to the teaching personnel, having staff members available to prepare for CRE labs is critical, particularly for CREs with more than one lab section. At Gonzaga University, where all 350-plus freshmen taking introductory biology are in a phage-discovery CRE, a full-time lab coordinator (with 
several student workers as assistants) is key to its successful implementation. This staff person coordinates all the faculty lab instructors, teaching assistants, open-lab teaching assistants, and prep assistants for the course, in addition to overseeing week-to-week logistics, student assignments, materials preparation, and assessment.

For courses with one or two sections, the instructor or researcher at Gonzaga typically does the prep work and manages the teaching assistants, with varying level of assistance for ordering supplies for the labs. In some cases, particularly with upper-division CREs, the students themselves are responsible for prepping the materials they need. Thus the logistical support varies with the size of the CRE. If staff positions are entirely supported by grants, sustaining the CREs is problematic. Therefore, we encourage institutions to fully fund these CRE-support positions to enable sustainable programs that benefit all students.

\section{Comparing CREs of Different Lengths}

Modular CREs. This format offers one or more multiweek research projects that are undertaken during a semesterwhich may be more effective at meeting particular educational goals than a semester- or year-long research experience. In this case, students gain the benefits of participating in the process of science and also benefit from learning a variety of skills, techniques, and application of concepts from other laboratory exercises. Modular CREs tend to be more engaging intellectually for faculty and students alike than more traditional labs. They also can be easier to implement both intellectually and practically than a semester-long CRE, and they are instrumental in providing introductory-level STEM majors with a research experience early in their careers.

The modular approach also works well in survey classes that introduce many different topics, because faculty can just replace one or two traditional labs with a modular CRE. In some courses, the modular format allows students to learn a variety of techniques needed for a research project that they then complete in the second part of the semester. Modular CREs also are valuable when the lab experience is instrumental in delivering content that a full-semester CRE may not cover. Furthermore, a modular CRE may serve as an effective compromise between faculty members who resist losing the content covered in traditional labs each week and those advocating for semester-length CREs. From the resource perspective, modular CREs may be a valuable strategy in order to expose all students to research, since semester-long CREs may not be feasible without additional staffing. A potential pitfall of modular CREs is that they may be more easily transformed, albeit unintentionally, into a cookbook experience.
In addition, with modular CREs, it can be harder to get students to appreciate them as enabling genuine research, rather than just a project. Furthermore, interest may be low if the module emphasizes technique rather than the research question.

Modular CREs can be especially critical for students who have never had a previous research experience. CREs are an unfamiliar environment for many students and carry expectations that many of them have not faced before-for example, redoing procedures until they work. In addition, because some beginning students seem intimidated by thinking and prefer to be told what to do every step of the way, modular CREs are an effective way to introduce these students to the research environment. In fact, CREs (of any sort) are great equalizers (Bangera and Brownell 2014). They make the research community more diverse by providing research experiences to all students, no matter the student's level of high school preparation. For this reason-to promote inclusive excellence-students are best served by required CREs in introductory classes (Bangera and Brownell 2014). For example, NC Central University, Smith College, Tuskegee University, Hope College, and Gonzaga University all run a CRE in the required lab for the introductory biology class.

Semester-long CREs. A semester-long (or year-long) CRE has the advantage of time. Techniques and skills can be developed over a semester with students redoing procedures until they are successful. In doing so, students have more time to truly understand not only what they're doing but also why they're doing it. In addition to practicing and perfecting techniques, the semester- or year-long CRE reinforces intellectual concepts and the understanding of what science is. For example, content in statistics can be learned in the fall semester, and then the knowledge used again and extended in the spring semester.

Faculty find semester- and year-long CREs more engaging to teach, with one faculty member summing this up by saying, "Most fun I've ever had teaching." Furthermore, well-designed CREs based on faculty research may productively contribute to the faculty's scholarship, which can be an important benefit for faculty at many liberal arts institutions. Another aspect of semester-long CREs is the benefit of building a community of scholars among students, teaching assistants, and the faculty mentors.

The challenge to semester-long (and year-long) CREs is finding a project amenable to the academic level of the student participants and one that can sustain their interest (and that of the faculty member). In some instances teaching a semester-long CRE can become tiresome, particularly if the re- 
search focus doesn't match that of the instructor. Mentoring large groups of novices is also time-consuming, and the continuous balancing act between providing enough structure and instruction and yet also fostering independent work can be taxing. Semester-long CREs can cost more in terms of faculty time as well.

Whatever the type of CRE implemented, faculty mentors note that the research experience helps students plan and better envision potential science careers. After a CRE, students are familiar with technical skills involved in research and also have a better understanding of what it's like to be a scientist. Another benefit is that CREs often provide a springboard for interested students to become involved in further research, as the following student comments show:

- "I purposely transferred into the research lab to get a jumpstart on 'real world' expectations. I seem to really enjoy doing experiments and gathering data; I may be cut out for research!"

- "Studying phages in this lab has sparked my educational interest and potential career interest in microbiology."

- "I was so confused as to what I should major in in my freshman year. This year, after giving science a shot, I have fallen in love and without a doubt this lab and semester have shown me that my passion lies in science and this will be, one way or another, what I end up doing in my future."

Each of our institutions has developed CREs that fit its curricular structure, faculty interests, student population, and resources. We readily acknowledge that faculty availability and resources, both physical and financial, may influence the types and extent of CREs that are developed and successfully implemented at a given institution. These factors need not be significant barriers to CRE adoption, however, because CREs can be developed in many ways (see Table 2), and there is not one right way to implement a CRE.

Transforming teaching and learning is too important to insist that such improvements proceed in only one way. Our very diverse experiences developing and implementing CREs indicate that laboratory courses can be effectively transformed in many different ways to successfully provide research experiences for undergraduates. Such transformations can be made incrementally, in a given course or in a given curriculum, without compromising the benefits. Knowing that the successful implementation of CREs does not require an all-ornothing approach should help motivated faculty begin the process and overcome the many real and perceived barriers (Brownell and Tanner 2012; Spell et al. 2014) to improving undergraduate science instruction and student outcomes. Furthermore, implementing CREs early in the curriculum is an effective mechanism to promote inclusive excellence by equalizing access to science across students' varied and disparate backgrounds (Bangera and Brownell 2014).

\section{Acknowledgments}

The collaboration that underpins this article was supported by grants to the authors' institutions from the Howard Hughes Medical Institute through its Undergraduate Science Education Program; the SEA-PHAGES program; the Genomics Education Partnership program; and by an NSF grant (DUE124577) to Gonzaga University. Gonzaga University's Institutional Review Board (IRB) for Human Subjects Research approved the study evaluating its phage course (IRB \#1404BIOAND). We thank colleagues and Sr. Joan Cordis Westhues for discussion of the issues in this article and Stanley K. Sessions for the wagon wheel in Figure 1.

\section{References}

American Association for the Advancement of Science [AAAS]. 2011. Vision and Change in Undergraduate Biology Education: A Call to Action. Washington, DC: Author. Accessed January 10, 2014 http://visionandchange.org/ files/2011/03/Revised-Vision-and-Change-Final-Report.pdf2011/03/RevisedVision-and-Change-Final-Report.pdf.

Auchincloss, Lisa Corwin, Sandra L. Laursen, Janet L. Branchaw, Kevin Eagan, Mark Graham, David I. Hanauer, Gwendolyn Lawrie, Colleen M. McLinn, Nancy Pelaez, Susan Rowland, Marcy Towns, Nancy M. Trautmann, Pratibha Varma-Nelson, Timothy J. Weston, and Erin L. Dolan. 2014. "Assessment of Course-Based Undergraduate Research Experiences: A Meeting Report." CBE-Life Sciences Education 13: 29-40. doi: 10.1187/ cbe.14-01-0004

Bangera, Gita, and Sara E. Brownell. 2014. "Course-Based Undergraduate Research Experiences Can Make Scientific Research More Inclusive." CBELife Sciences Education 13: 602-606. doi: 10.1187/cbe.14-06-0099.

Beck, Christopher W., and Lawrence S. Blumer. 2014. "A Handbook on Bean Beetles, Callosobruchus maculatus." Accessed from Bean Beetles: A Model Organism for Inquiry-based Undergraduate Laboratories, Laboratory Methods, http://www.beanbeetles.org.

Brownell, Sara E., and Kimberly D. Tanner. 2012. "Barriers to Faculty Pedagogical Change: Lack of Training, Time, Incentives, and...Tensions with Professional Identity?" CBE—Life Sciences Education 11: 339-346. doi: 10.1187/cbe.12-09-0163.

Brownell, Sara E., Daria S. Hekmat-Scafe, Veena Singla, Patricia Chandler Seawell, Jamie F. Conklin Imam, Sarah L. Eddy, Tim Stearns, and Martha S. Cyert. 2015. "A High-Enrollment Course-Based Undergraduate Research Experience Improves Student Conceptions of Scientific Thinking and Ability to Interpret Data." CBE—Life Sciences Education 14: ar21. doi: 10.1187/cbe.1405-0092. 
Buck, Laura B., Stacey Lowery Bretz, and Marcy H. Towns. 2008. "Characterizing the Level of Inquiry in the Undergraduate Laboratory." Journal of College Science Teaching 38(1): 52-58.

Campbell, A. Malcolm, and Barbara Lom. 2006. “A Simple E-Mail Mechanism to Enhance Reflection, Independence, and Communication in Young Researchers." CBE-Life Sciences Education 5: 318-322. doi: 10.1187/ cbe.06-06-0170.

Corwin, Lisa A., Mark J. Graham, and Erin L. Dolan. 2015. “Modeling Course-Based Undergraduate Research Experiences: An Agenda for Future Research and Evaluation." CBE_Life Sciences Education 14: 1-13. doi: 10.1187/cbe.14-10-0167.

D'Avanzo, Charlene. 1996. "Three Ways to Teach Ecology Labs by Inquiry: Guided, Open-Ended, and Teacher-Collaborative." Bulletin of the Ecological Society of America 77(2): 92-93.

Eagan, M. Kevin, Sylvia Hurtado, Mitchell J. Chang, Gina A. Garcia, Felisha A. Herrera, and Juan C. Garibay. 2013. "Making a Difference in Science Education: The Impact of Undergraduate Research Programs." American Educational Research Journal 50: 683-713. doi: 10.3102/0002831213482038.

Graham, Mark J., Jennifer Frederick, Angela Byars-Winston, Anne-Barrie Hunter, and Jo Handelsman. 2013. "Increasing Persistence of College Students in STEM." Science 341:1455-1456. doi: 10.1126/science.1240487.

Hatfull, Graham F. 2015. "Innovations in Undergraduate Science Education: Going Viral." Journal of Virology 89: 8111-8113. doi: 10.1128/jvi.03003-14.

Jordan, Tuajuanda C., Sandra H. Burnett, Susan Carson, Steven M. Caruso, Kari Clase, Randall J. DeJong, John J. Dennehy, Dee R. Denver, David Dunbar, Sarah C. R. Elgin, Ann M. Findley, Chris R. Gissendanner, Urszula P. Golebiewska, Nancy Guild, Grant A. Hartzog, Wendy H. Grillo, Gail P. Hollowell, Lee E. Hughes, Allison Johnson, Rodney A. King, Lynn O. Lewis, Wei Li, Frank Rosenzweig, Michael R. Rubin, Margaret S. Saha, James Sandoz, Christopher D. Shaffer, Barbara Taylor, Louise Temple, Edwin Vazquez, Vassie C. Ware, Lucia P. Barker, Kevin W. Bradley, Deborah Jacobs-Sera, Welkin H. Pope, Daniel A. Russell, Steven G. Cresawn, David Lopatto, Cheryl P. Bailey, and Graham F. Hatfull. 2014. "A Broadly Implementable Research Course in Phage Discovery and Genomics for First-Year Undergraduate Students." mBio 5(1): e01051-13. doi: 10.1128/mbio.01051-13.

Lopatto, David. 2004. "Survey of Undergraduate Research Experiences (SURE): First Findings." Cell Biology Education 3: 270-277. doi: 10.1187/ cbe.04-07-0045.

Seymour, Elaine, Anne-Barrie Hunter, Sandra L. Laursen, and Tracee DeAntoni. 2004. "Establishing the Benefits of Research Experiences for Undergraduates in the Sciences: First Findings from a Three-Year Study." Science Education 88: 493-534. doi: 10.1002/sce.10131.

Shaffer, Christopher D., Consuelo Alvarez, Cheryl Bailey, Daron Barnard, Satish Bhalla, Chitra Chandrasekaran, Vidya Chandrasekaran, Hui-Min Chung, Douglas R. Dorer, Chunguang Du, Todd T. Eckdahl, Jeff L. Poet, Donald Frohlich, Anya L. Goodman, Yuying Gosser, Charles Hauser, Laura L.M. Hoopes, Diana Johnson, Christopher J. Jones, Marian Kaehler, Nighat Kokan, Olga R. Kopp, Gary A. Kuleck, Gerard McNeil, Robert Moss,
Jennifer L. Myka, Alexis Nagengast, Robert Morris, Paul J. Overvoorde, Elizabeth Shoop, Susan Parrish, Kelynne Reed, E. Gloria Regisford, Dennis Revie, Anne G. Rosenwald, Ken Saville, Stephanie Schroeder, Mary Shaw, Gary Skuse, Christopher Smith, Mary Smith, Eric P. Spana, Mary Spratt, Joyce Stamm, Jeff S. Thompson, Matthew Wawersik, Barbara A. Wilson, Jim Youngblom, Wilson Leung, Jeremy Buhler, Elaine R. Mardis, David Lopatto, and Sarah C.R. Elgin. 2010. "The Genomics Education Partnership: Successful Integration of Research into Laboratory Classes at a Diverse Group of Undergraduate Institutions." CBE-Life Sciences Education 9: 55-69. doi: 10.1187/09-11-0087.

Shellito, Cindy, Kalyn Shea, Gary Weissmann, Anke Mueller-Solger, and William Davis. 2001. "Successful Mentoring of Undergraduate Researchers." Journal of College Science Teaching 30: 460-464.

Siritunga, Dimuth, María Montero-Rojas, Katherine Carrero, Gladys Toro, Ana Vélez, and Franklin A. Carrero-Martínez. 2011. “Culturally Relevant Inquiry-based Laboratory Module Implementations in Upper-Division Genetics and Cell Biology Teaching Laboratories." CBE_Life Sciences Education 10: 287-297. doi: 10.1187/cbe.11-04-0035.

Spell, Rachelle M., Judith A. Guinan, Kristen R. Miller, and Christopher W. Beck. 2014. "Redefining Authentic Research Experiences in Introductory Biology Laboratories and Barriers to Their Implementation." CBE-Life Sciences Education 13: 102-110. doi: 10.1187/cbe.13-08-0169.

Staub, Nancy L., Marianne Poxleitner, Amanda Braley, Helen SmithFlores, Christine M. Pribbenow, Leslie Jaworski, David Lopatto, and Kirk R. Anders. 2016. "Scaling Up: Adapting a Phage-Hunting Course to Increase Participation of First-Year Students in Research." CBE-Life Sciences Education 15(2): 1-11. ar13. doi: 10.1187/cbe.15-10-0211.

Tanner, Kimberly D. 2009. "Talking to Learn: Why Biology Students Should Be Talking in Classrooms and How to Make It Happen." CBE-Life Sciences Education 8(2): 89-94. doi: 10.1187/cbe.09-03-0021.

Thiry, Heather, Timothy J. Weston, Sandra L. Laursen, and Anne-Barrie Hunter. 2012. "The Benefits of Multi-Year Research Experiences: Differences in Novice and Experienced Students' Reported Gains from Undergraduate Research." CBE-Life Sciences Education 11: 260-272. doi: 10.1187/cbe.11-110098.

Travis, John. 2003. "All the World's a Phage: Viruses that Eat Bacteria Abound-and Surprise." Science News 164(2): 26-28. doi: 10.2307/3982016.

Weaver, Gabriela C., Cianán B. Russell, and Donald J. Wink. 2008. "Inquirybased and Research-based Laboratory Pedagogies in Undergraduate Science." Nature Chemical Biology 4: 577-580. doi: 10.1038/nchembio1008-577.

Wilson, Zakiya S., Lakenya Holmes, Monica R. Sylvain, Lisa Batiste, Misty Johnson, Saundra Y. McGuire, Su Seng Pang, and Isiah M. Warner. 2012. "Hierarchical Mentoring: A Transformative Strategy for Improving Diversity and Retention in Undergraduate STEM Disciplines." Journal of Science Education and Technology 21(1): 148-156. doi:10.1007/s10956-011-9292-5.

Zimmer, Carl. 2012. A Planet of Viruses. Chicago, IL: University of Chicago Press. doi: 10.7208/chicago/9780226983332.001.0001. 


\section{Nancy L. Staub}

Gonzaga University, staub@gonzaga.edu

Nancy L. Staub, professor of biology at Gonzaga University, studies salamander gland evolution with undergraduates, teaches a wide range of classes, and is program director of Gonzaga's Howard Hughes Medical Institute grant through the Undergraduate Science Education Program. She has facilitated development of coursebased research at Gonzaga for many years.

Lawrence S. Blumer, professor of biology at Morehouse College, studies animal behavior, ecology, and evolutionary biology, particularly of insects. In collaboration with Christopher W. Beck, he has developed the Bruchid bean beetle, Callosobruchus maculatus, as a model organism for inquiry-based undergraduate laboratories.

Christopher W. Beck is professor of pedagogy at Emory University. He is studying the effect of inquiry-based learning on student understanding of the nature of science and the scientific process. With collaborator Lawrence S. Blumer, Beck developed the Bruchid bean beetle, Callosobruchus maculatus, as a model system for inquiry-based lab classes in biology.

Véronique Delesalle is a professor of biology at Gettysburg College. She is the program director of Gettysburg College's grant from the Howard Hughes Medical Institute through the Undergraduate Science Education Program. Their grant is designed to keep students actively engaged in research throughout the curriculum. She co-taught the SEA-PHAGES program at Gettysburg College for its first four years.

Gerald D. Griffin, assistant professor of biology at Tuskegee University, is a neurovirologist whose research interests focus on the reciprocal interactions between neurotropic viruses and neurons. He joined the psychology faculty at Hope College in fall 2015.

Robert B. Merritt, professor of biological sciences at Smith College, has served as program director of its Howard Hughes Medical Institute grant for undergraduate science education. Merritt studies the evolutionary mechanisms influencing the genetic structure of populations in a wide range of organisms, including both plants and animals. He has taught CREs for many years.

Bettye Sue Hennington, professor of biology, established the Proteomics/Mass Spectrometry Center at Tougaloo College and studies hypertension. She is the retired program director for Tougaloo's Howard Hughes Medical Institute grant for undergraduate science education.
Wendy H. Grillo is an associate professor of biology at North Carolina Central University. Her research interests includes implementing research into undergraduate science courses, exploring what motivates students to learn, and improving students' metacognitive awareness. Grillo has an extensive research background in improving undergraduate science education. She is an alumna of the American Society for Microbiology Biology Scholars Research Residency Program.

Gail P. Hollowell is an associate professor of biology at North Carolina Central University and leads many science-education activities within the department. Her current research interests include infusing research into the science curriculum, the impact of technology in the science classroom, and studying what motivates students to learn science. Hollowell serves as co-director for the university's Howard Hughes Medical Institute grant for undergraduate science education. She also is principal investigator for the HBCUs as Leaders in STEM and Education grant from the University of Pennsylvania Graduate School of Education.

Sandra L. White, professor and director of the Center for Science, Math, and Technology at North Carolina Central University, is a biomedicine researcher with more than 40 years of experience as a faculty member and department chair. For the last 10 years she has developed and implemented numerous science education programs in STEM fields for middle-school, high-school, and college students. She is the program director for the university's Howard Hughes Medical Institute's undergraduate science education grant.

Catherine M. Mader, a professor of physics at Hope College, also conducts workshops for teachers and high school students on nuclear science and nuclear forensics. She is the director of the Day 1 Research Communities program at Hope College. She is the program director for Hope College's undergraduate science education grant from the Howard Hughes Medical Institute and also for the collaboration grant given to this article's coauthors focusing on implementation of CREs on their campuses.

\section{doi: $10.18833 /$ curq/37/2/11}

